\title{
Perancangan Sistem Navigasi Robot Kapal Katamaran untuk Menghindari Rintangan Menggunakan Logika Fuzzy
}

\author{
Rossi Passarella*, Kemahyanto Exaudi dan Sayyidatina Fatimah \\ Jurusan Sistem Komputer, Fakultas Ilmu Komputer, Universitas Sriwijaya \\ *Corresponding author, e-mail: Passarella.rossi@unsri.ac.id
}

\begin{abstract}
Abstrak - Robot kapal katamaran adalah sebuah kapal robot yang memiliki 2 buah lambung tambahan disisi kanan dan kiri yang berfungsi untuk menjaga kestabilan robot kapal. Pada penelitian ini dilakukan perancangan sistem navigasi pergerakan atau manuver robot kapal yang ditentukan oleh pergerakan rudder yang berada di buritan kapal dan dikendalikan secara otomatis mengadopsi teknik logika fuzzy Sugeno. Input logika fuzzy ini didapat dari kamera yang terletak pada haluan robot kapal. Input ini dibagi menjadi 3 menggunakan proses pengolahan citra berupa daerah kiri, tengah dan kanan. Hasil dari perhitungan fuzzy berupa nilai sudut yang dikirimkan ke motor servo untuk menggerakkan rudder. Pergerakan kapal katamaran menjadi baik.
\end{abstract}

\section{Kata Kunci : Fuzzy Logic Sugeno, , Robot Kapal Katamaran, Rudder, Sistem Navigasi}

\begin{abstract}
The robotic ship Katamaran is a robotic ship which has two extra hulls at both side. The existence of the hulls aims to keep the ship balance. The navigation of the robot or known as maneuver is set by the movement towards rudder which is installed at stern of ship. To do this Fuzzy Sugeno Logic is applied. The input of this fuzzy logic is obtained by camera which is placed at the prow. The input is an image video, the image then separated out three areas by using image processing which is being formed into left area, middle area, and right area. As the result of fuzzy calculation is the angle which is sent to the servo motors to move the rudder. The maneuver of the robotic ship katamaran, has a good level.
\end{abstract}

Keywords : Fuzzy Logic Sugeno, Robot Kapal Katamaran, Rudder, Sistem Navigasi

\section{Pendahuluan}

Teknologi robot saat ini telah berkembang dengan pesat. Salah satu pengembangan yang dilakukan para peneliti berupa robot kapal. Robot kapal identik dengan robot yang mampu mengontrol pergerakannya berdasarkan navigasi. Navigasi merupakan metode yang dapat menentukan arah gerak robot secara otomatis [1].

Saat ini telah banyak peneliti yang mengembangkan sistem navigasi robot kapal menggunakan logika fuzzy [2, 3]. Hal ini terlihat dari berbagai penelitian dan pengembangan yang dilakukan oleh pemerintah maupun akademisi di lingkungan kampus. Penelitian dilakukan dalam upaya menciptakan sebuah sistem pengendalian otomatis yang dapat meminimalisir tingkat resiko kecelakaan dalam pelayaran [4]. Pengendalian otomatis untuk menghindari halangan sangat diperlukan pada kapal untuk menghindari terjadinya tabrakan dengan kapal lain ataupun objek lainya. Penelitian ini merancang suatu sistem pergerakan otomatis pada robot kapal katamaran.

Pada umumnya kapal dikendalikan oleh Nakoda atau kapten kapal yang menggunakan mata untuk mengetahui lingkungan disekitar kapal, sehingga dapat mengendalikan atau menavigasi pergerakan kapal. Untuk mentransformasi fungsi mata dalam memberikan informasi sekitar kapal, maka digunakan kamera. Sedangkan untuk memberikan kecerdasan kepada kapal untuk menentukan pergerakanya secara otomatis digunakan metode logika fuzzy sugeno. Hasil yang didapat kamera selanjutnya akan di proses menggunakan metode pengolahan citra untuk membagi gambar menjadi 3 zona sehingga proses logika fuzzy sugeno dapat dilakukan berdasarkan 3 zona input untuk mendeteksi objek halangan.

\section{Tinjauan Pustaka}

Sistem pergerakan otomatis pada robot kapal katamaran menggunakan metode fuzzy logic sugeno. Dalam sistem pergerakan kapal ini, 
digunakan kamera sebagai sensor. Sensor kamera ini digunakan sebagai media pengolahan gambar yang menjadi navigasi robot kapal, kamera akan mendeteksi keadaan di depan robot kapal yang kemudian akan memberikan output pada kendali robot.

\subsection{Kapal Katamaran}

Katamaran merupakan salah satu bentuk kapal dimana terdiri dari dua buah lambung yang bertujuan untuk mendapatkan kapal yang memiliki stabilitas ruang yang luas, namun hanya memerlukan daya mesin yang kecil [5].

Katamaran termasuk jenis kapal yang memiliki struktur bridging. Struktur bridging ini merupakan suatu keuntungan katamaran karena menambah tinggi lambung timbul (freeboard) [5]. Kapal katamaran tersebut dapat dilihat pada gambar 1.

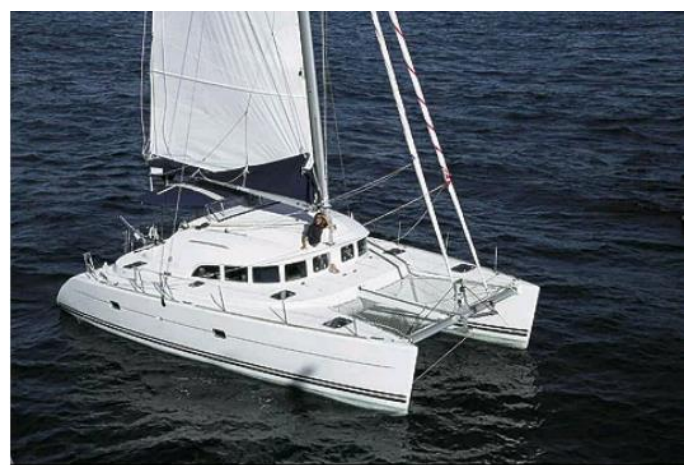

Gambar 1. Kapal Katamaran

\subsection{Pengolahan Citra}

Citra digital adalah citra yang dapat diolah langsung oleh komputer. Citra digital diperoleh melalui proses pencuplikan objek tiga dimensi oleh sistem penangkapan citra yang kemudian dibentuk suatu matriks dimana elemen-elemenya menyatakan nilai intensitas cahaya [6]. Pada penelitian ini, akan terdapat tiga proses pengolahan citra yaitu grayscale, biner, dan thresholding.

\subsection{Logika Fuzzy}

Sistem fuzzy mempunyai beberapa keuntungan bila dibandingkan dengan sistem tradisional, misalkan pada jumlah aturan yang dipergunakan. Proses logika fuzzy pada awalnya mengubah nilai crisp input menjadi fuzzy input dengan fungsi keanggotaan yang ditentukan di dalam fuzzy-fikasi. Selanjutnya nilai tersebut dirancang untuk suatu aturan logika sebagai pengambilan keputusan dalam sistem kontrol. Hal ini disebabkan karena sistem fuzzy mempunyai kemampuan untuk memberikan respon berdasarkan informasi yang bersifat kualitatif, tidak akurat, dan ambigu [7].

Didalam kendali logika fuzzy, kinerja kendali memuaskan atau tidak juga tergantung dari trial and error [8]. Pendekatan fuzzy melibatkan aturanaturan yang dinyatakan dalam kata-kata dan tidak memerlukan presisi yang tinggi serta ada toleransi untuk data yang kurang tepat. Gambar 2 menunjukkan diagram blok pengendali logika fuzzy .

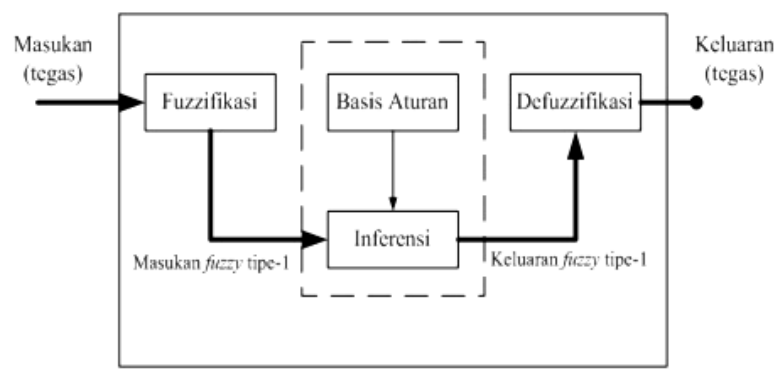

Gambar 2. Diagram blok pengendali logika Fuzzy

\section{Metoda Penelitian}

Pada penelitian ini perancangan dibagi menjadi dua bagian utama, yaitu perancangan hardware robot kapal dan perancangan software. Kedua sistem ini diintegrasikan menjadi sebuah sistem pergerakan robot kapal berbasis logika fuzzy.

\subsection{Perancangan Hardware Robot Kapal}

Perancangan hardware robot kapal ini terdiri dari beberapa bagian, yaitu kamera, laptop, mikrokontroller ATMega dan motor servo. Diagram blok perancangan perangkat keras robot kapal ini dapat dilihat pada Gambar 3.

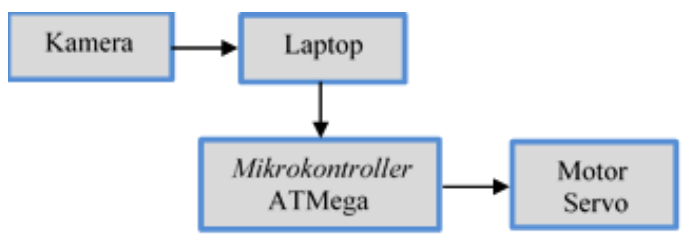

Gambar 3. Diagram blok prancangan hardware robot kapal

Pada perancangan ini kamera diletakkan dibagian depan robot kapal yang berfungsi sebagai sensor penghindar halangan. Citra yang diterima oleh kamera akan diproses menjadi menjadi tiga 
bagian wilayah yaitu kiri, tengah dan kanan. Pengolahan citra dari hasil kamera ini diproses menggunakan laptop yang diletakkan pada bagian dalam kapal.

Komunikasi data yang digunakan dalam proses pengiriman data gambar dilakukan menggunakan teknologi Bluetooth. Sedangkan mikrokontroler yang digunakan adalah jenis ATMega8535. ATMega ini memiliki media transfer $\mathrm{Rx}$ dan Tx yang terhubung langsung dengan komunikasi bluetooth secara serial.

Robot kapal ini juga dilengkapi dengan motor servo. Motor servo ini mampu bergerak secara dua arah (CW dan $\mathrm{CCW}$ ) dengan defleksi masingmasing sudut mencapai $90^{\circ}$ sehingga total defleksi sudut dari kanan, tengah dan kiri adalah $180^{\circ}$.

\subsection{Perancangan Software}

Perancangan software pada robot kapal ini digunakan untuk pemrosesan gambar dengan menggunakan pengolahan citra dan program pengendali motor servo. Gambar 4 menunjukkan diagram blok perancangan software robot kapal.

Tahapan-tahapan yang dilakukan dalam mendisain software pengolahan citra berdasarkan data kamera adalah sebagai berikut.

\subsubsection{Pengolahan Citra Digital}

Pada tahap ini citra digital didapat secara realtime dari kamera yang terpasang didepan robot kapal. Citra gambar ditangkap oleh kamera berukuran 640 x 320 pixel. Untuk melakukan proses pengolahan citra, resolusi diubah menjadi $320 \mathrm{x}$ 240 pixel. Hal ini dilakukan agar pemrosesan data citra lebih cepat. Data citra digital diolah untuk menghasilkan citra warna 24 bit. 8 bit pertama mewakili nilai warna biru, 8 bit kedua mewakili nilai warna hijau dan 8 bit terakhir mewakili nilai warna merah. Setiap point pixel RGB Citra warna ini mempunyai informasi yang berbeda-beda.

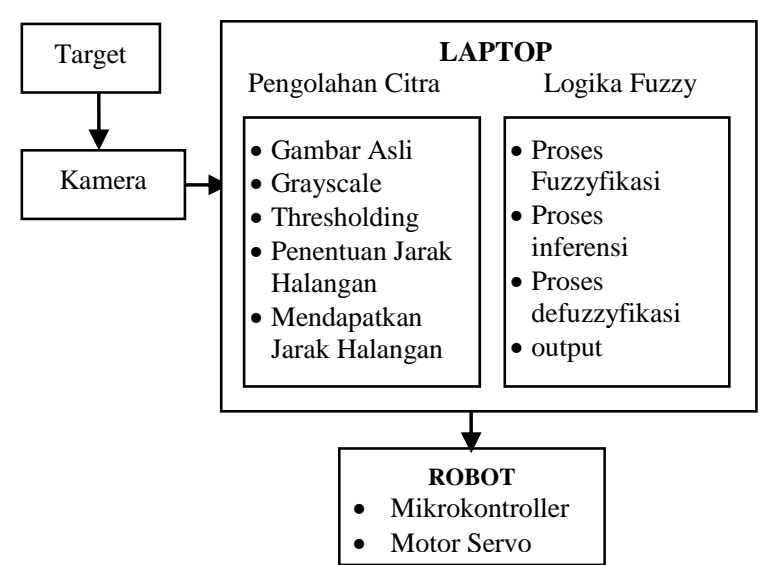

Gambar 4. Diagram Blok Rancangan Software Robot Kapal

\subsubsection{Thresholding}

Proses thresholding ini dilakukan untuk mendapatkan nilai grayscale pada setiap pixel dari citra yang diproses. Hasil pemrosesan citra dapat langsung dieksekusi berdasarkan nilai grayscale dan nilai ambang dari citra yang diproses. Hasil dari proses ini dibagi menjadi dua kemungkinan nilai pixel, yaitu nilai pixel 255 (putih) dan nilai pixel 0 (hitam). Nilai pixel 255 diperoleh saat nilai pixel citra grayscale lebih besar dari nilai ambang yang telah ditentukan. Sedangkan nilai pixel 0 diperoleh saat nilai pixel citra grayscale lebih kecil dari nilai ambang. Setelah eksekusi seluruh pixel citra selesai hasil akhir yang didapatkan yaitu pixel hitam dan putih.

\subsubsection{Penentuan Jarak Halangan}

Pembagian wilayah citra berfungsi untuk mengetahui keberadaan halangan. Tiga pembagian wilayah citra, yaitu wilayah kiri, tengah dan kanan Setelah halangan pada setiap wilayah terdeteksi maka dapat ditentukan jarak antara robot kapal dengan halangan.

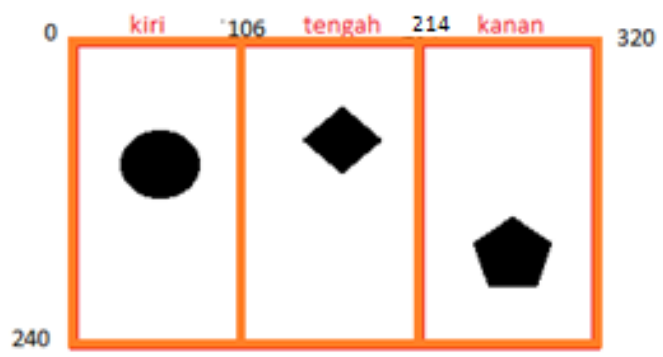

Gambar 5. Hasil pembagian wilayah citra dan letak halangan yang terdeteksi

Untuk mengetahui jarak robot kapal dengan 
halangan dilakukan perhitungan pixel vertical pada wilayah tertentu. Gambar 5 menunjukkan hasil pembagian wilayah citra dan letak halangan yang terdeteksi.

Gambar 5 menunjukkan bahwa jarak halangan paling dekat terletak pada koordinat (x, 240). Semakin jauh halangannya maka semakin kecil nilai koordinat sumbu y. Setelah mendapatkan jarak halangan maka system dapat mendeteksi jarak pada tiga wilayah yang telah ditentukan. Kemudian menentukan nilai y maksimum pada masing masing wilayah

\subsubsection{Deteksi jarak Halangan}

Setelah pembagian daerah sensor dilakukan dan jarak halangan telah didapat maka langkah selanjutnya adalah mengkonversi pixel ke jarak halangan sebenarnya yaitu dalam satuan centimetre $(\mathrm{cm})$. Proses kalibrasi pixel ke jarak (cm) dapat dilihat pada Gambar 6.

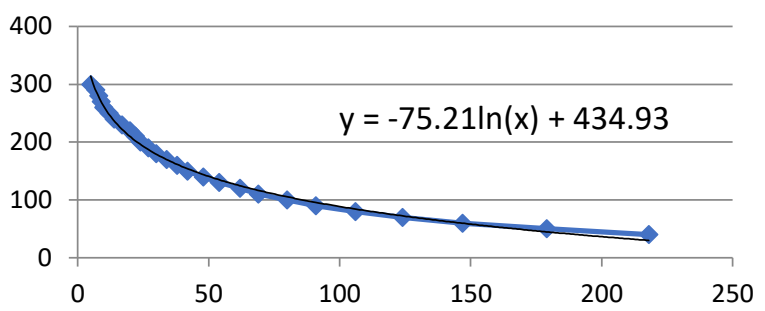

Gambar 6. Proses kalibrasi pixel ke jarak (cm)

Pada Gambar 6 terlihat bahwa kalibrasi menghasilkan persamaan yaitu $\mathrm{y}=-75.21$ $\ln (\mathrm{x})+434.93$, dimana y merupakan nilai jarak dan $\mathrm{x}$ merupakan nilai pixel. Dengan menggunakan persamaan ini maka akan didapat jarak yang sebenarnya.

Pada penelitian ini pergerakan robot kapal berdasarkan putaran sudut motor servo. Untuk mengontrol servo bergerak dari tengah (00) ke kanan / CW (900) dan dari tengah (00) ke kiri / CCW (180) dilakukan proses kalibrasi pada servo dan didapatkan persamaan kalibrasi $\mathrm{y}=0.1736 \mathrm{x}+$ 31.248 .

\subsubsection{Perancangan Logika Fuzzy}

Logika fuzzy memiliki beberapa keunggulan diantaranya:

a. Konsep mudah dimengerti dikarenakan penalaran logika fuzzy sangat sederhana.

b. Bersifat fleksibel

c. Memilki toleransi terhadap data yang tidak tepat.

d. Mampu memodelkan fungsi non-linier yang kompleks

e. Tanpa melalui proses pelatihan

f. Mampu bekerja dengan teknik-teknik kendali secara konvensional

Sistem kendali logika fuzzy memiliki beberapa jenis diantaranya mamdani dan sugeno. Untuk menentukan jenis fuzzy logic yang digunakan diperlukan model inferensi yang tepat. Model mamdani biasanya digunakan untuk masalah intuitif sedangkan sugeno digunakan untuk menangani kontrol atau kendali.

Berdasarkan penjelasan diatas, metode logika fuzzy sugeno diterapkan dengan masukan dari kamera yang terletak pada bagian depan robot kapal dan digunakan sebagai pengontrol pergerakan motor robot. Sistem logika fuzzy sugeno ini terdiri dari tiga komponen utama yaitu fuzzifikasi, basis aturan, dan defuzzyfikasi.

\section{a. Proses Fuzzifikasi sugeno}

Fuzzifikasi merupakan suatu proses untuk mengubah suatu masukan dari bentuk nilai pasti (crisp input) menjadi fuzzy input (variabel linguistik) yang biasa disajikan dalam bentuk himpunan-himpunan fuzzy dengan suatu fungsi keanggotaannya. Sistem pergerakan pada robot kapal katamaran ini menggunakan kamera sebagai sensor. Sensor kamera dibagi 3 pembagian wilayah dimana tiap wilayah sensor memiliki fungsi keanggotaan dan tiga variabel linguistik. Pembentukan variablel linguistik ditunjukan pada Tabel 1.

Tabel 1. Input Sensor Kamera

\begin{tabular}{|c|c|c|}
\hline Jarak (cm) & Variabel Linguistik & Keterangan \\
\hline $0-200$ & Dekat & D \\
$30-310$ & Sedang & S \\
$200-320$ & Jauh & J \\
\hline
\end{tabular}

Berdasarkan variabel linguistik yang telah ditentukan maka himpunan fuzzy berdasarkan fungsi keangggotaan yaitu: dekat, sedang, jauh seperti yang ditunjukan pada Gambar 7 .

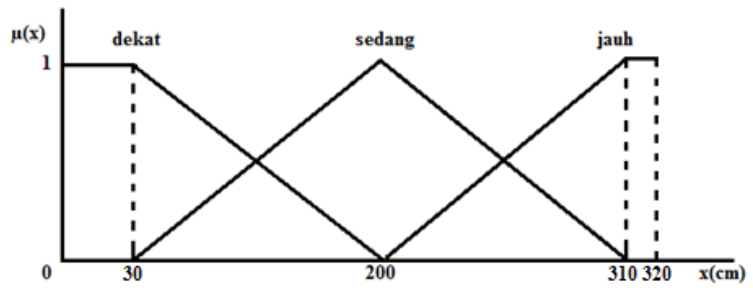

Gambar 7. Grafik fungsi kanggotaan 
Berdasarkan fungsi keanggotaan yang digunakan maka fungsi persamaannya dapat ditulis sebagai berikut :

$$
\begin{aligned}
& \mu \text { dekat }[x]=\left\{\begin{array}{ccc}
1 & \text { untuk } & x \leq 30 \\
\frac{200-x}{200-30} & \text { untuk } & 30<x \leq 200 \\
0 & \text { untuk } & x>200
\end{array}\right\} \\
& \mu \operatorname{sedang}[x]=\left\{\begin{array}{ccc}
0 & \text { untuk } & x<30 \\
\frac{x-30}{200-30} & \text { untuk } & 30 \leq x<200 \\
\frac{310-x}{310-200} & \text { untuk } & 200 \leq x<310 \\
0 & \text { untuk } & x>310
\end{array}\right\} \\
& \operatorname{\mu jauh}[x]=\left\{\begin{array}{ccc}
0 & \text { untuk } & x<200 \\
\frac{x-200}{310-200} & \text { untuk } & 200 \leq x<310 \\
1 & \text { untuk } & 310 \leq x \leq 320
\end{array}\right\}
\end{aligned}
$$

\section{b. Basis Aturan}

Pada penelitian ini ditentukan fungsi keanggotaan data output fuzzy seperti terlihat pada Gambar 8 .

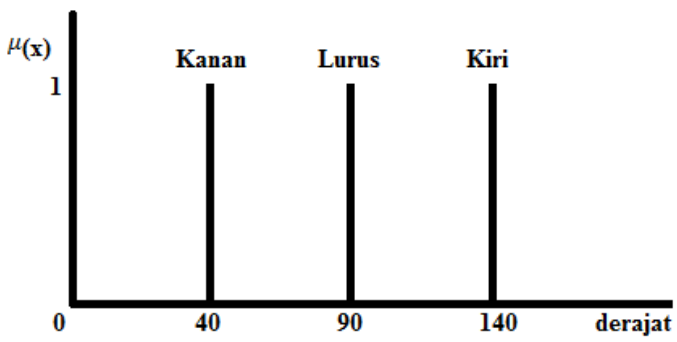

Gambar 8. Fungsi keanggotaan output motor servo

\section{Mekanisme Aturan}

Setelah merancang basis aturan, selanjutnya melakukan proses pengambilan keputusan. Dimana pada proses pengambilan keputusan ini digunakan mekanisme Max-Min seperti terlihat pada persamaan (1)

$$
\begin{aligned}
& \mu_{B}(y)=\max \left[\min \left[\mu_{A 1}(\operatorname{input}(i)), \ldots\right]\right] \\
& {\left[\left[\mu_{A 2}(\operatorname{input}(j)), \mu_{A 3}(\operatorname{input}(k)), \ldots\right]\right]}
\end{aligned}
$$

Pada mekanisme aturan Max Min pengambilan keputusan dilakukan pada operasi conjuction dan disjunction

\section{c. Defuzzyfikasi}

Metode yang digunakan pada proses defuzzifikasi ini adalah Weight Average. Metode ini mengambil nilai rata-rata dengan menggunakan pembobotan berupa derajat keanggotaan. Persamaan metode weight average ini dapat dilihat pada persamaan (2) dibawah ini.

$$
y=\frac{\sum \mu(y) y}{\sum \mu(y)}
$$

dimana y adalah nilai crisp dan $\mu$ (y) yaitu derajat keanggotaan dari nilai crisp y.

\subsubsection{Output}

Pada tahapan ini output yang dihasilkan dari proses defuzzifikasi berupa nilai derajat. Dari nilai derajat yang didapat ini akan diketahui pergerakan motor ke kiri, lurus atau ke kanan. Motor akan bergerak ke kanan jika nilai derajat kurang dari atau sama dengan 40 derajat, motor akan bergerak lurus jika nilai derajat lebih dari 40 derajat dan kurang dari atau sama dengan 90 derajat dan motor akan bergerak ke kiri jika nilai derajat lebih dari 90 derajat atau kurang dari sama dengan 140 derajat. Setelah didapat nilai derajat tersebut maka proses selanjutnya yaitu mengirim nilai derajat yang diperoleh dari proses fuzzy ke mikrokontroler menggunakan bluetooth.

\section{Hasil dan Pembahasan}

\subsection{Pengujian Pergerakan Robot}

Pengujian dilakukan pada arena kolam dengan cuaca cerah dan tidak hujan. Pengujian ini dilakukan untuk melihat apakah robot kapal bisa bergerak menghindari halangan disekitarnya. Pergerakan robot kapal dapat dilihat pada Gambar 9 dimana robot bergerak kekanan, dan bergerak lurus, Gambar 10 menunjukkan robot bergerak kekiri dan menghindari halangan bergerak.

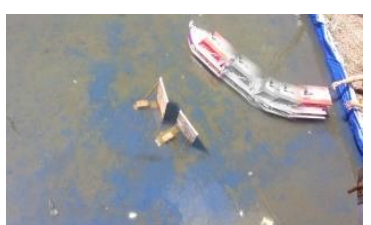

$\mathrm{a}$

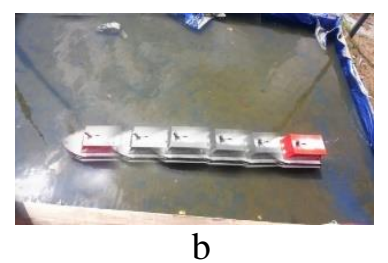

b
Gambar 9. Pergerakan ke kanan (a) dan Pergerakan Lurus (b)

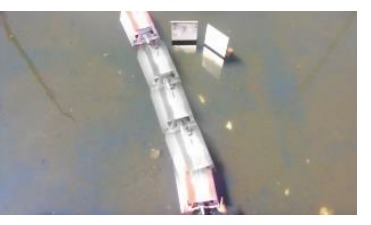

a

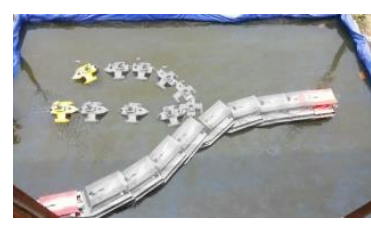

b
Gambar 10. Pergerakan ke Kiri (a), menghindari halangan bergerak (b)

Grafik pergerakan robot saat menghindari halangan disekitarnya dapat dilihat pada Gambar 
11 yang menunjukkan grafik pergerakan robot kearah kanan, Gambar 12 yang menunjukkan grafik pergerakan robot lurus, Gambar 13 yang menunjukkan grafik pergerakan kekiri dan Gambar 14 yang menunjukkan grafik robot menghindari halangan bergerak.

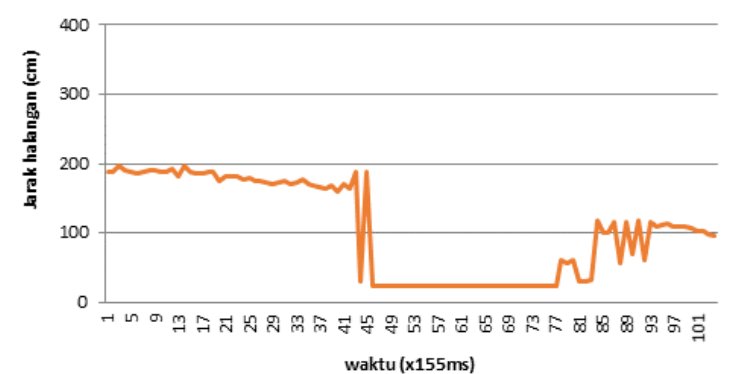

Gambar 11. Grafik Pergerakan robot kearah kanan

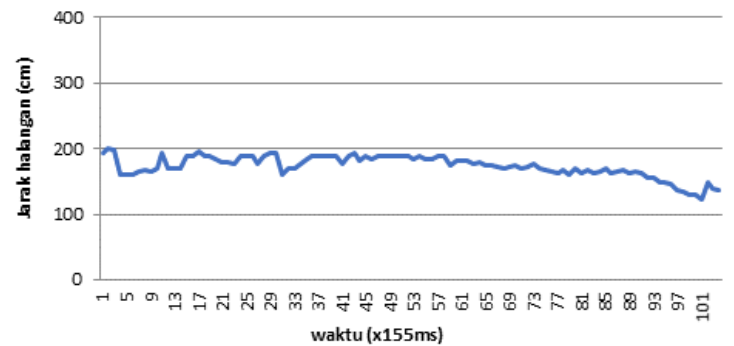

Gambar 12. Grafik Pergerakan robot lurus

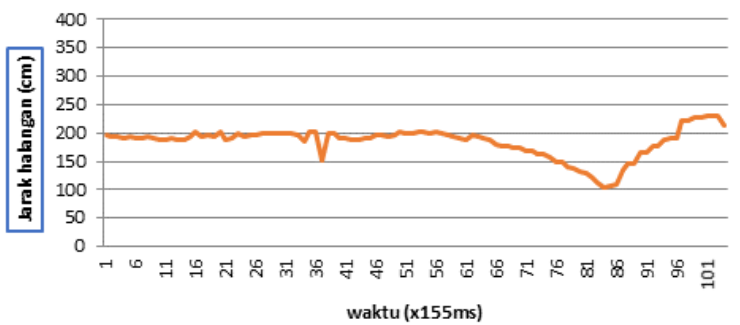

Gambar 13. Grafik Pergerakan kearah kiri

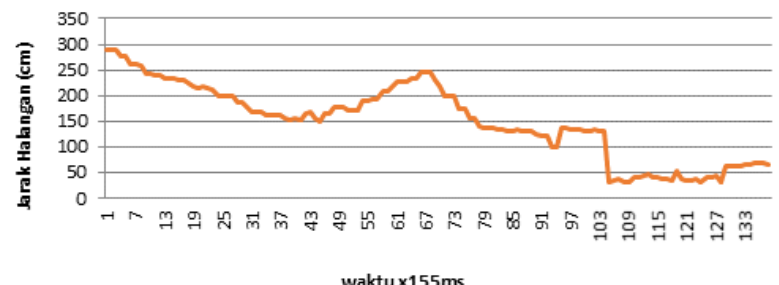

Gambar 14. Grafik Pergerakan dengan halangan bergerak

\subsection{Pergerakan Robot Bebas}

Pada pengujian ini robot kapal bergerak secara bebas pada arena kolam dan dihadapkan dengan halangan yang bergerak berupa robot kapal kecil dan juga halangan diam. Hal ini dilakukan untuk mengetahui kinerja sensor robot dalam berbagai kondisi dilapangan. Pergerakan robot kapal dapat dilihat pada Gambar 15. Sedangkan grafik pergerakan bebas robot dapat dilihat pada Gambar 16.

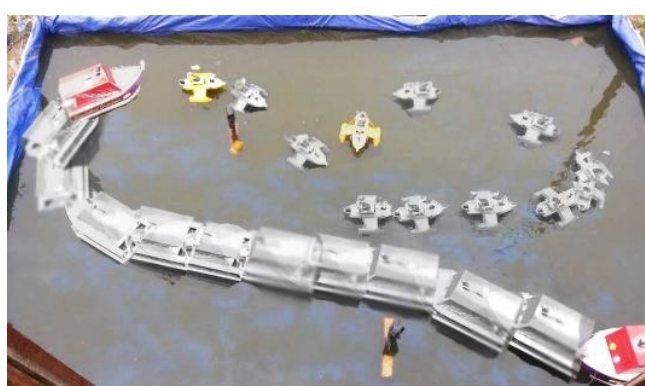

Gambar 15. Pergerakan bebas robot

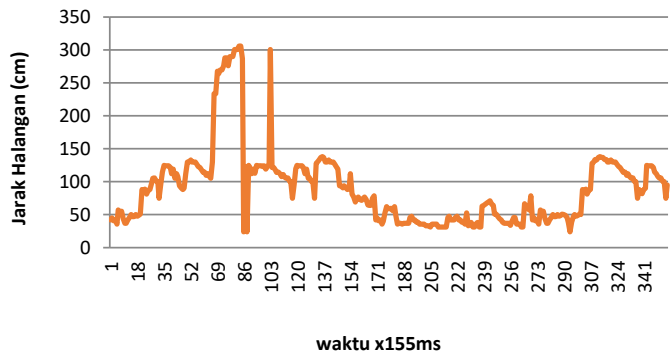

Gambar 16. Grafik Pergerakan bebas robot

\subsection{Validasi Data Simulasi}

Untuk mengetahui hasil pengujian yang telah dilakukan sebelumnya apakah telah sesuai dengan nilai yang diharapkan atau tidak maka dilakukan validasi perhitungan fuzzy logic sugeno menggunakan program simulasi. Validasi ini menggunakan simulasi Fuzzy Inference System Editor seperti terlihat pada Gambar 17.

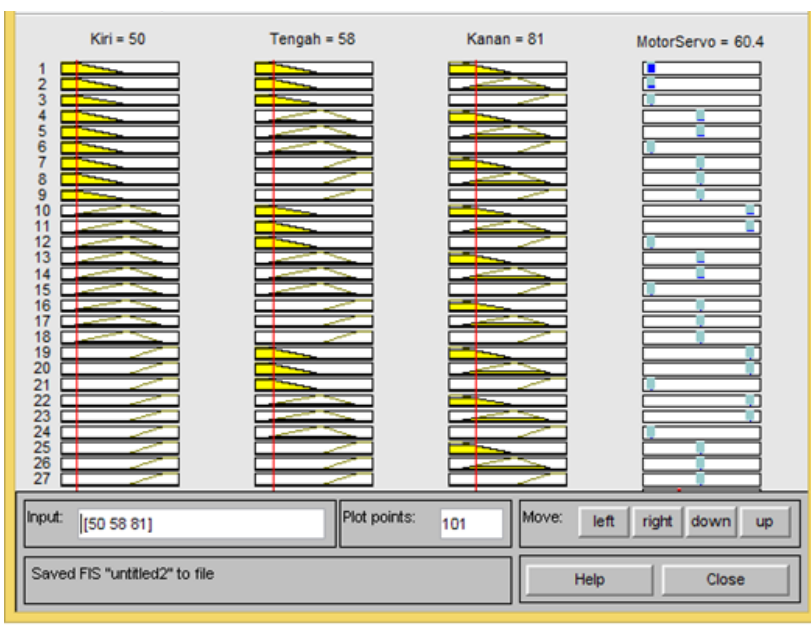

Gambar 17. Hasil dari validasi simulasi Fuzzy Inference System Editor

https://doi.org/10.25077/jnte.v7n1.446.2018 jnte.ft.unand.ac.id 


\section{Kesimpulan}

Berdasarkan hasil pengujian dan analisa pada sistem pergerakkan robot kapal katamaran yang menggunakan fuzzy logic menunjukkan bahwa system mampu bekerja dengan baik sebagai alat navigasi robot kapal secara otomatis. Dengan menggunakan teknik thresholding robot kapal katamaran dapat membedakan dengan jelas antara obstacle dan bukan obstacle serta menghasilkan pergerakan robot kapal yang baik.

\section{Daftar Pustaka}

[1] Nurmaini, S. dan Tutuko, B., A New Classification Technique in Mobile Robot Navigation, Telkomnika, Vol. 9, No. 3, hal 453-464, 2011

[2] Sembiring, S., Baafai, U., dan Tarigan, P., Implementasi Arsitektur Behavior-Based dengan Menggunakan Fuzzy untuk Navigasi Car-Like Mobile Robot dalam Lingkungan yang Tak Dikenal, Jurnal Generic, Vol. 9, No. 2, hal 320-331, 2014.

[3] Darwison dan Rian Wahyudi., Kontrol Kecepatan Robot Hexapod Pemadam Api menggunakan Metoda Logika Fuzzy, Jurnal Nasional Teknik Elektro (JNTE), Vol. 4, No. 2, 2015.

[4] Anitasari, Ruri dkk., Perancangan sistem kendali manufer untuk menghindari tabrakan pada kapal tangki berbasis logika fuzzy. Jurnal. Institut Teknologi Sepuluh November, 2009
[5] Aji Sera Sakti, I.K.A.P. Utama. Analisis CFD dan Eksperimen hambatan Lambung Katamaran Asimetris Flat Side Outside dengan Variasi Jarak Demihull. Jurnal. KAPAL- Institut Teknologi Sepuluh November.Vol. 9, No.3 Oktober 2012.

[6] Putra, Darma.. Pengolahan Citra Digital. ANDI Yogyakarta, 2010

[7] Sri Kusumadewi, Artificial Intelegence (Teknik dan aplikasinya), edisi pertama. Penerbit Graha Ilmu, Jakarta, 2003

[8] Muhlis, Nur, Perancangan Kontroler Kaskade Fuzzy untuk Pengaturan Tekanan Pada Pressure Control Trainer 38-714, 2010.

\section{Biodata Penulis}

Rossi Passarella, menyelesaikan sarjana di universitas sriwijaya jurusan Teknik elektro. Kemudian menyelesaikan magister di UKM Malaysia. Sekarang berstatus sebagai Dosen Sistem Komputer Universitas Sriwijaya, saat ini menjabat sebagai Ketua jurusan sistem komputer.

Kemahyanto Exaudi, menyelesaikan sarjana di universitas sriwijaya jurusan Sistem Komputer. Kemudian menyelesaikan magister di ITS Surabaya. Sekarang berstatus sebagai Dosen Teknik Komputer di Program Diploma Komputer Universitas Sriwijaya.

Sayyidatina Fatimah, terdaftar sebagai mahasiswa jurusan system computer di Fakultas Ilmu Komputer Universitas Sriwijaya pada tahun 2009, kemudian menyelesaikan gelar sarjana tahun 2015. Saat ini sedang bekerja di perusahaan yang bergerak dibidang Kontrol. 